\title{
The Research of the Characteristics of University Students's Processing Sports Information
}

\author{
Chuanfang Wang \\ P.E. Department, Luoyang Institute of Science and Technology \\ Luoyang, Chian \\ email: wchuanfang @163.com
}

\begin{abstract}
By means of documents, questionnaire, interviewing experts, the quantitative and qualitative analysis and data statistics and processing, some basic conditions are learned, including the basic types of sports information's dissemination carriers, university students' motive to learn sport information, their media information attainment, sports behaviors, individual's use and acceptance of sports information. Relative reaearch variables are used to analyze university students' cognitive degree of sports media information and their mutual satisfying relationship, the relationship between sports behaviors and sports information, the relationship between college student's sports information input and output and the differences of students'acceptance of sports information under different stutus.
\end{abstract}

Keywords-sports information; sports behaviors; information input and output; acceptance motive, informaiton carrier

\section{RESEARCH OBJECTIVES}

Sports information (SI) can broadcast, lead and modify people's productive activities and daily life and has a great influence on university students'(USS) body-building ideas and behaviors. Its development mainly depends on people's sports cognition and value. Nowadays, SI education is an important part of information education in universities and has become an important index of personnel training.

Improving the efficiency of USS's accepting and using sports information can increase the development of sports cultural education. We should carry out different kinds of sports activities to show SI to people and encourage people to participate in these activities. It is necessary to update SI and smooth information transmission channels, create sports culture atmosphere and direct USS to take part in Sunshine Sports activities so that they can know sports better and strengthen their bodies.

As far as SI is concerned, this article is mainly about USS's sports cognition, accepting tunnels, accepting motive and the relationship between USS's sports information input and output

\section{RESEARCH METHODS}

\section{A. Document-data Method}

Relative information is acquired by reading some articles about SI and sports behaviors of USS in China Academic Journals Full-text Database and consulting relative books and materials in the library.

\section{B. . Questionnaire Method}

Based on the objectives and content of the research, the questionnaire, College Students' Sports Behaviors and Media Literacy, was made. According to the distribution of universities in Henan province, multi-step sampling and random sampling were adopted and ten universities in Henan province were chosen to engage in the research, including Zhengzhou University, Henan University, Luoyang Institute of Science Anyang Teachers College, Xinyang Teachers College, Nanyang Teachers College, Xuchang College, Henan Institute of Science and Technology and Huanghuai College, and so on. Fifty questionnaires were posted to each college and questionnaires were distributed randomly to students in different departments. Five hundred questionnaires were distributed totally and 485 were retrieved. 410 are valid, effective percentage is 80.2. To ensure the validity and efficiency of the survey, expert validity test and split-half reliability test were done and proved that $r=0.785$, which is significant in statistics.

\section{Mathematical Statistics Method}

Statistical analysis computer program SPSS17.0 was used to do the analysis and the following methods were adopted: descriptive statistic, chi square test, one-factor analysis of variance, correlation analysis, and so on.

\section{DATA AND ANALYSIS}

\section{A. Different Media through which USS Accept SI}

Human beings' carving for knowledge provides motive for the constant updating of modern communication means. what kind of media and what kind of media content are chosen by USS not only depends on their particular living envi- 
ronment and practical demands, but also have an important relationship with their own cognitive structure. Research results prove that USS accept sports information mainly through the following tunnels: watching TV (27.3\%), surfing the Internet (20.2\%), listening to the radio (17.3\% ). By contrast, they seldom read newspapers, magazines and books. This indicates that some media, for example, TV, Internet, are accepted by most students because they have some advantages which can enlarge students' imaginary space, such as, enormous information, rapid updating, wonderful tone, vibrant pictures, good simulation results. However, traditional media are not efficient at storing, comprehending, memorizing information.

\section{B. USS' Cognition Degree of SI and their Motive to use $S I$}

Media can improve the development of information quickly and properly and the content and forms of SI can affect students' mode of thinking and behaviors and improve their media attainment.

TABLE 1 UNIVERSITY STUDENT' COGNITIVE DEGREE OF SPORT INFORMATION

\begin{tabular}{cccc}
\hline Choices & Frequency & Percent & Valid Percent \\
\hline $\begin{array}{c}\text { Very } \\
\text { Important }\end{array}$ & 103 & 25.1 & 25.1 \\
Important & 126 & 30.7 & 30.7 \\
Normal & 87 & 21.2 & 21.2 \\
Not Very & 56 & 13.7 & 13.7 \\
Important & 38 & 9.3 & 9.3 \\
Not Important & 410 & 100.0 & 100.0 \\
Total & & & \\
\hline
\end{tabular}

Table 1 proves that USS' cognitive degree of SI is relatively high. 55.8\% subjects think that SI is important for their life and study and only 9\% subjects think that it isn't important.

In addition, over 55\% subjects agree on the choice “ Improving university students' media attainment is an import part of modern life.”. This indicates that many students realize the importance of SI, which is inseparable with students' artistic appreciation, cognitive ability, sports education they have received, the propaganda of media and their personal feelings. After having received sports education for more than ten years, students can understand the basic concept and value of SI gradually. Furthermore, students received systemic, standard, various sports education so that they have a across-the-aboard understanding of the function of SI

By analysis, we can find that students' motive for using sports media is as following: improving their understanding of sports information (27.2\%), finding solutions to some problems $(27.5 \%)$, celebrity's appeal (15.1\%), entertainment $(12.1 \%)$, killing time $(7.5 \%)$, and so on. This indicates that students can treat sports media reasonably and make good use of sports media content to satisfy their own needs. In addition, many students worship some sports stars so that they would like to learn some sports information.

Table 2 USS' MOTIVE TO USE SI AND THEIR RECOGNITION OF SI

\begin{tabular}{cccc}
\hline Variable & $\begin{array}{c}\text { Pearson Corre- } \\
\text { lation Test }\end{array}$ & $\begin{array}{c}\text { Information } \\
\text { Motive }\end{array}$ & $\begin{array}{c}\text { Attainment } \\
\text { Recogniton }\end{array}$ \\
\hline Information & $\begin{array}{c}\text { Pearson } \\
\text { Correlation }\end{array}$ & 1 & .683 \\
Motive & Sig. (2-tailed) &. & \\
& $\mathrm{N}$ & 410 & \\
& Pearson & .683 & .020 \\
Information & Correlation & .020 & 410 \\
Recognition & Sig. (2-tailed) & .020 & 410 \\
& $\mathrm{~N}$ & 410 & \\
\hline
\end{tabular}

As is shown in Table 2, USS' motive to accept and use SI is correlated with their SI recognition to some degree ( $\mathrm{r}=0.683$ ), which proves that modern university students can make good use of sports media and their media attainment is high. Therefore, improving the circulation of information and strengthening students' contact with the outside world is helpful to develop students' attainment.

\section{The Relationship between USS'Accepting SI and their sports behaviors}

Getting to know some SI, such as, sports knowledge, sports matches, sports entertainment information, can improve students concern about sports, cultivate their interest to do sports and lay a strong foundation for life-long sports. The more SI students receive, the more actively they do sports, the more adequately they realize the significance of doing sports and the more possibly they can form right sports value.

Research results prove that university students accept SI actively and use it for self-development. SI they receive mainly includes sports matches $(28.3 \%)$, interviews of famous athletes (16.6\%) , sports appreciation (12.0\%), sports entertainment programs (15.1\%) , body building (19.0\%) , sports industry and sports goods (7.8\%), others $(1.2 \%)$. This indicates that sports matches are studnets' favorite program, the next is body-building programs. We can find that students are inclined to some exciting, real, visual sports content. Besides, students are apt to watch some exciting matches and accept some practical information, whereas they accept less sports theories, especially some knowledge about Olympics. Even so, they have a perceptual cognition of sports, which can improve their individual sports behaviors. 
Table 3 THE RELATIONSHIP BETWEEN USS'ACCEPTING SI AND TIEIR SPORTS BEHAVIORS

\begin{tabular}{|c|c|c|c|c|}
\hline Test & Variable & $\begin{array}{c}\text { Correlation } \\
\text { Test }\end{array}$ & $\begin{array}{l}\text { Receiving } \\
\text { Frequency }\end{array}$ & $\begin{array}{l}\text { Exercising } \\
\text { Frequency }\end{array}$ \\
\hline \multirow{6}{*}{$\begin{array}{l}\text { Kendall's } \\
\text { tau_b }\end{array}$} & \multirow{3}{*}{$\begin{array}{l}\text { Receiving } \\
\text { Informati } \\
\text { on }\end{array}$} & $\begin{array}{l}\text { Correlation } \\
\text { Coefficient }\end{array}$ & 1.000 & .515 \\
\hline & & $\begin{array}{l}\text { Sig. (2- } \\
\text { tailed) }\end{array}$ & . & .026 \\
\hline & & $\mathrm{N}$ & 410 & 410 \\
\hline & \multirow{3}{*}{$\begin{array}{c}\text { Sports } \\
\text { Behavior }\end{array}$} & $\begin{array}{l}\text { Correlation } \\
\text { Coefficient }\end{array}$ & .515 & 1.000 \\
\hline & & $\begin{array}{l}\text { Sig. (2- } \\
\text { tailed) }\end{array}$ & .026 & . \\
\hline & & $\mathrm{N}$ & 410 & 410 \\
\hline
\end{tabular}

As is shown in Table 3, USS' sports behavior is moderate correlated with their receiving SI $(r=0.515)$, which indicates that students who receive and use SI don' $t$ do sports very actively. That is, many students are just interested in browsing some SI while they don't take part in various sports activities.

\section{Analysis and Discussion of the Gap between USS' Accepting SI and their using SI}

Information gap refers to the gap between an individual's input and output of SI, that is, the gap between the SI quantity that a student accepts and inputs and the SI quantity that he spreads and outputs.

Each subject is regarded as a unit and there are two variables, SI input quantity and SI output quantity. Whether there is gap between them is analyzed. SI input quantity can be defined as the time integration of reading SI $\left(\triangle \mathrm{L}_{0}\right)$ and an individual' $s$ output quantity of SI $\left(\triangle \mathrm{L}_{1}\right)$. By analysis, we can find that $r=\triangle L_{1} / \triangle L_{0}=0.254$, that is,USS' input and output of SI is unbalanced and their SI input quantity is much more than their SI output quantity.

Table 4 THE RELATIONSHIP BETWEEN SI INPUT QUANTITY AND SI OUTPUT QUANTITY

\begin{tabular}{cccc}
\hline Variable & Test Methods & $\begin{array}{c}\text { Time Integra- } \\
\text { tion }\end{array}$ & Complexity \\
\hline \multirow{2}{*}{$\begin{array}{c}\text { Pearson } \\
\text { Correlation }\end{array}$} & 1 & .254 \\
Integration & Sig. (2-tailed) &. & -.056 \\
& $\mathrm{~N}$ & 410 & 410 \\
& Pearson & .254 & 1 \\
Informatio & Correlation & -.056 &. \\
n Output & Sig. (2-tailed) & 410 & 410 \\
\hline
\end{tabular}

The reasons may be following: students may deal with SI in different ways and different students' cognition of SI is in different levels so that they perceive SI in different levels. There are various SI, but many students accept SI just for entertainment. Besides, nowadays, there aren't enough sports organizations in universities of Henan province, sports organizations don't carry out various activities frequently and time isn't fixed. Besides, students seldom organize activities voluntarily.

\section{E. the Difference among USS' Accepting and Using SI under theBackground of Society}

Students differ from each other. Their family may be poor or rich and they have different majors.

USS' sports consumptive level is relatively low. Overtop structure is determined by economic basis. Students' consumptive ability is determined by their economic condition. Nowadays, university students' economic condition in Henan province isn't very good. $27.9 \%$ of the subjects have 251-300 RMB to spend every month. There are many students who can only spend less than 100 RMB every month. Students differ from each other economically. The research proves that there is no difference among students from cities, towns and the countryside concerning receiving sports information.

By doing one-factor analysis of variance, we can find that there isn't significant difference among students in different departments concerning SI cognition. USS generally accept SI and SI has a good influence on their study, lfe and self- development. Knowing SI can broaden their outlook and improve their ability to accept, comprehend, memorize and use information.

\section{CONCLUSIONS}

USS receive SI in many different ways, among which watching TV and surfing the Internet are the most popular while traditional media are used less frequently. Most of them recognize the importance of SI and there is no difference among students in different departments. Their motive to get SI is to know the dynamic change of sports events. USS' sports behavior is moderate correlated with their receiving SI. USS'input and output of SI is imbalanced. There isn't significant difference among students from different families and in different departments concerning SI acceptance.

\section{ACKNOWLEDGEMENTS}

This soft science project of the Science and Technology Department of Henan Province one of the initial results of the "College Physical Education intersubjective trust sight" (122400440114)

\section{REFERENCES}

[1] Fang Jianyi and Zhang Qin, Media Psychology, Zhejiang: Zhejiang University press, 2004, pp.54.

[2] $\mathrm{Hu}$ Zhengrong, General Mass Communication, Beijing: Communication University of China press, 2007, pp.259.

[3] Meng Nansheng, Media Planning and Marketing, Beijing: Communication University of China press, 2007, pp.151-153.

[4] Cao Lei and Ge Xin, the Influence of Mass Media on University Students' Participating in Sports activities, Journal Harbin Physical Education Institute, Vol. 2. 2006. 
[5] Wang Chuanfang, Analysis and Research on Sport Consumption Condition and Influence Factors of College Students In Henan Province, Bulletin of sport science and technology, vol.12. 2008. 